\title{
Pengelolaan Sampah oleh Masyarakat Perkotaan di Kota Yogyakarta
}

\author{
Vidyana Arsanti dan Sri Rum Giyarsih
}

\begin{abstract}
Garbage is one of urgent problems in urban area. The lack of idle lands in urban area make garbage problems more difficult. This research is conducted in Yogyakarta City that has been done the garbage management successfully.

Objective of the research is to describe and classify the garbage management models implemented by the society. This research uses survey methods that is encode the region where the garbage management is implemented, with the direct interview to respondents and questionnaire as a means of data collecting. The descriptive analysis is applied in this research.

The research shows that garbage management activity that has been applied in some locations is good enough by developing three model of garbage management. This research also suggests networking among government, society figure, and urban society to reach the best garbage management.
\end{abstract}

Keywords: garbage management, urban society

\section{Pengantar}

Sampah merupakan barang sisa yang sudah tidak berguna lagi dan harus dibuang. Padahal sebetulnya sampah merupakan "mutiara terpendam" yang akan memancarkan kilaunya atau bermanfaat kalau dikelola secara tepat (Basriyanta, 2007). Menurut Rineksa (2007), meningkatnya kesejahteraan masyarakat dan kemajuan peradaban manusia telah diikuti dengan pola hidup yang semakin konsumtif. Kebutuhan hidup manusia semakin beragam dan masyarakat pun menjadi bersifat konsumtif. Budaya masyarakat yang konsumtif ini cenderung mengeksploitasi sumberdaya alam yang sekaligus menurunkan kualitas lingkungan hidup, yang diakibatkan oleh peningkatan limbah padat (sampah), cair, maupun gas.

Masalah sampah semakin komplek, volume sampah kian membumbung dari hari ke hari karena terpicu oleh semakin pesatnya pembangunan permukiman. Sistem dan teknologi untuk menangani sampah juga sulit dan mahal. Walaupun telah dilibatkan teknologi tinggi dan mutakhir, masalah lingkungan hidup tidak berarti teratasi, jika produk sampah tetap tinggi maka sehebat apapun alat atau manajemen yang dilakukan, maka tidak akan sanggup untuk mengatasi. Sampah akan menggunung dari hari ke hari, apalagi jumlah penduduk semakin banyak (Sucipto, 1998).

Outerbridge (1991) menyatakan bahwa dalam kegiatan pengelolaan sampah secara komunal ini, banyak pertimbangan ketika akan memilih sebuah proses pengelolaan sampah, pilihan proses tersebut tergantung dan dipengaruhi pada beberapa faktor, yaitu: (1) jenis sampah yang dikelola 
seperti sampah rumah tangga maupun sampah industri, (2) pertimbangan geografis seperti kondisi lingkungan tempat kegiatan pengelolaan sampah, (3) keterampilan dan ketersediaan tenaga kerja, yaitu keterampilan atau pendidikan yang dimiliki penduduk dan adanya peran serta atau perilaku aktif/keaktifan penduduk (penduduk sebagai tenaga kerja) dalam kegiatan pengelolaan sampah, (4) dana yang tersedia untuk modal maupun biaya operasi, yaitu berupa uang, barang ataupun jasa, dan (5) penggunaan utama dari produk kegiatan, seperti untuk dijual atau untuk digunakan sendiri, misalnya hasil kompos dijual atau digunakan sendiri untuk pupuk tanaman.

Selain faktor-faktor tersebut pakar ini juga menyebutkan adanya faktor lain yang dinilai dapat mempengaruhi dalam pengelolaan sampah yaitu kelembagaan atau kegiatan sosial yang ada dan pendampingan. Kelembagaan atau kegiatan sosial misalnya rapat atau pertemuan dengan pengurus kampung, arisan, pengajian, pertemuan PKK, pertemuan karang taruna, dan sebagainya. Dengan adanya kegiatan-kegiatan tersebut maka sosialisasi program pengelolaan sampah dapat dilakukan dengan mudah, sosialisasi ini bertujuan untuk meningkatkan kesadaran masyarakat agar mau mengelola sampah dengan prosedur yang telah ditetapkan dan menyamakan persepsi/cara pandang dengan bermusyawarah dalam hal pengelolaan sampah. Pembinaan, yaitu badan atau orang yang membimbing dan mengarahkan serta sebagai pendamping atau konsultan dalam kegiatan pengelolaan sampah.

Sementara itu pakar lain yaitu Basriyanta (2007), proses pengelolaan sampah saat ini, apabila ditinjau dari metode 3R + $1 \mathrm{D}$ yaitu: (1) reduce, proses meminimalisasi jumlah timbunan sampah dari sumbernya; (2) reuse, proses memilih dan memilah serta mengoptimalkan fungsi sampah yang masih bisa dimanfaatkan; (3) recycle, proses mengolah kembali sampah yang masih bisa diproses ulang menjadi barang lain yang bermanfaat, layak pakai, serta layak jual; (4) disposal, proses pembuangan akhir sampah yang memang sudah tidak bisa dimanfaatkan kembali.

Lebih jauh Basriyanta (2007) menyatakan bahwa berkaitan dengan sampah khususnya sampah rumah tangga (sampah domestik), akan lebih efektif dan efisien apabila pengelolanya dilakukan bersama secara komunal, dimulai dalam satu lingkup yang kecil (keluarga, kampung). Hal ini karena keluarga merupakan bagian inti dari suatu kampung atau wilayah. Apabila setiap keluarga bisa mengelola sampahnya masing-masing secara efektif dan efisien, maka dapat dipastikan kebersihan lingkungan sekitar juga terjaga. Selain itu, Kampung atau RW merupakan miniatur dari wilayah. Apabila dalam satu kampung masyarakatnya sadar dan mau bekerja sama mengelola sampah dengan baik dan benar, maka dapat diharapkan kampung tersebut akan memiliki lingkungan yang bersih, sehat, dan menyenangkan.

Penelitian ini bertujuan untuk mendeskripsikan dan mengklasifikasikan model-model pengelolaan sampah yang dilakukan oleh masyarakat berdasarkan karakteristik cara pengelolaannya, 
kelembagaan pengelolaannya, biaya pengelolaannya, pembinaannya, dan jenis sampah yang dikelola yang dilakukan oleh masyarakat perkotaan di Kota Yogyakarta.

\section{Metode Penelitian}

Metode yang digunakan dalam penelitian ini adalah survai. Pengumpulan data dilakukan dengan wawancara langsung kepada responden, yaitu penggerak kegiatan pengelolaan sampah di lokasi penelitian. Analisis data dilakukan secara deskriptif kualitatif. Penelitian dilakukan di wilayahwilayah dalam administrasi Kota Yogyakarta yang telah melakukan pengelolaan sampah dengan pertimbangan: (1) wilayah-wilayah tersebut sudah melakukan pengelolaan sampah secara mandiri, (2) adanya perbedaan lingkungan yang mempengaruhi teknik pengelolaan sampah yang diterapkan, dan (3) perkembangan penduduk di wilayah-wilayah tersebut yang pesat.

\section{Hasil dan Pembahasan}

\section{Pengelolaan Sampah di RW 10 Gondolayu Lor, Cokrodiningratan, Jetis, Yogyakarta}

RW 10 Gondolayu Lor terletak di belakang Hotel Santika, memiliki 210 kepala keluarga. Wilayah ini merupakan wilayah yang padat penduduknya dengan kepadatan penduduk 14.000 jiwa/ $\mathrm{Km}^{2}$. Semua rumah penduduk di Gondolayu tidak memiliki halaman rumah, hanya sebatas emperan atau teras saja. Jarak antar rumah penduduk pun hampir tidak ada, saling berdempet-dempetan dan hanya dibatasi dengan jalan kecil (gang).

Dengan adanya gambaran fisik wilayah yang demikian itu, maka dapat dipastikan bahwa produksi sampah yang dihasilkan penduduk di wilaya ini sangat besar, namun pertanyaannya, kemanakah sampah-sampah rumah tangga tersebut. Jawabannya adalah diangkut oleh gerobak sampah untuk dibuang di TPS Pemerintah Kota Yogyakarta yang selanjutnya diangkut ke TPA Piyungan.

Dengan latar belakang yang demikian, salah satu penduduk asli di Gondolayu Lor mengemukakan pendapat untuk diadakan kegiatan pengelolaan sampah mandiri di wilayah Gondolayu Lor khususnya RW 10. Setelah melalui kegiatan musyawarah yang panjang akhirnya disepakati bahwa warga di RW 10 Gondolayu Lor bersedia melakukan kegiatan pengelolaan sampah mandiri yang diawali dengan kegiatan pemilahan sampah anorganik dengan sampah organik pada tanggal 1 Januari 2006. Untuk menambah pengetahuan tentang kegiatan pengelolaan sampah, maka warga melakukan studi banding ke wilayah yang sudah terlebih dahulu melakukan kegiatan pengelolaan sampah mandiri, yaitu wilayah Dusun Sukunan, Kecamatan Gamping, Kabupaten Sleman. Karena 
adanya perbedaan situasi dan kondisi lingkungan, maka tidak mungkin teknik yang diterapkan di Sukunan diterapkan di RW 10 Gondolayu Lor. Dengan adanya kegiatan PKK dan pertemuan yang lain maka dimusyawarahkan kembali teknik pengelolaan sampah yang disesuaikan dengan situasi perkotaan yaitu pengelolaan sampah yang pas untuk Gondolayu Lor. RW 10 Gondolayu Lor dipilih untuk wilayah percontohan sebagai pelaksana wilayah percontohan pemilahan sampah agar ditiru oleh wilayah perkotaan yang lain, maka di RW 10 Gondolayu Lor dibentuklah "Kelompok Lingkungan Hidup Bumi Lestari” yang menangani lingkungan, khususnya pengelolaan sampah. Dengan bantuan ESP (Environment Service Programm), Dinas Lingkungan Hidup Kota Yogyakarta, LSM Hijau, Patmaya Unilever, dan masyarakat RW 10 Gondolayu Lor, maka kegiatan pengelolaan sampah berjalan dengan baik. Di wilayah ini kurang lebih 50\% penduduk yang aktif melakukan kegiatan pengelolaan sampah. Berikut adalah skema pengelolaan sampah di RW 10 Gondolayu Lor.

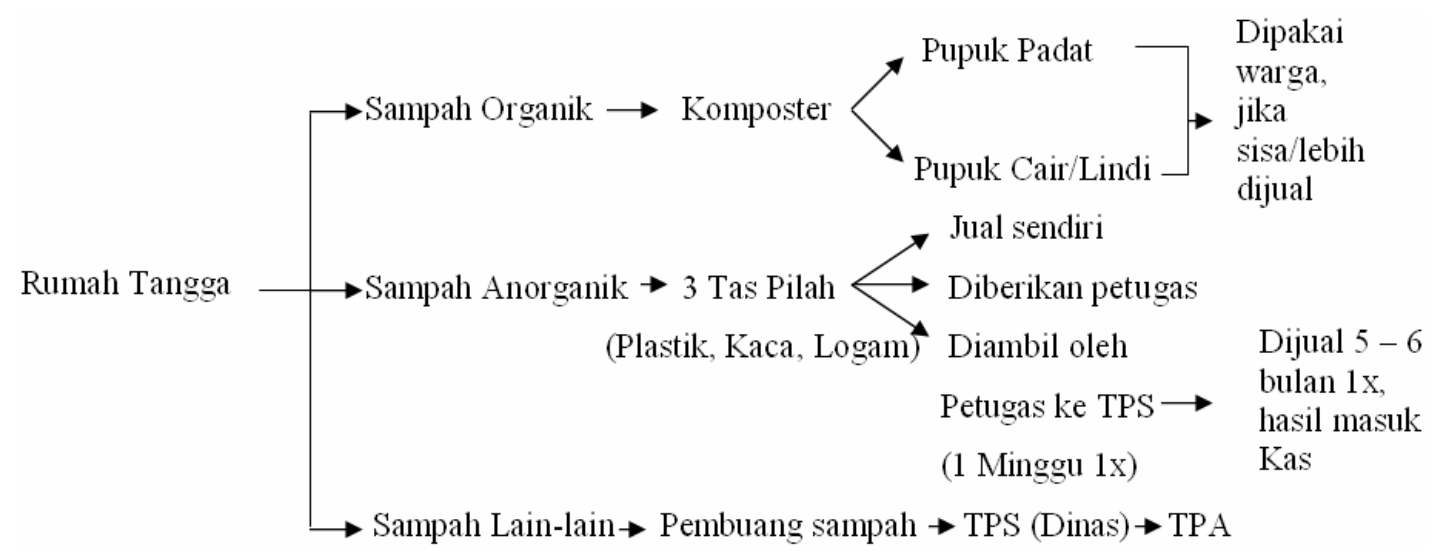

Gambar 1. Skema Pengelolaan Sampah di RW 10 Gondolayu Lor

Kendala yang dihadapi warga dalam kegiatan pengelolaan sampah yaitu untuk membenahi peralatan dalam kegiatan pengelolaan sampah sesudah gempa Yogyakarta pada tanggal 27 Mei 2006. Pada saat gempa terjadi, banyak peralatan pengelolaan sampah yang rusak, seperti emberember komposter dan peralatan yang lain. Untuk mengganti kerusakan alat-alat tersebut, masyarakat masih mengalami kesulitan dana. Dalam kegiatan pengelolaan sampah sebelumnya sudah menghabiskan dana sebesar Rp 22.006.000,--

\section{Pengelolaan Sampah di RT 45, RW 08 Gambiran Lor, Pandean, Umbulharjo, Yogyakarta}

RT 45 Gambiran Lor ini memiliki 191 kepala keluarga, merupakan wilayah yang memiliki kondisi dan situasi seperti halnya perumahan, kondisi yang tertata rapi menuntut adanya kebersihan lingkungan agar tercipta lingkungan yang bersih dan sehat. Masih banyaknya lahan kosong yang ada, menjadi potensi utama dalam kegiatan pengelolaan sampah yang diterapkan. Namun, warga 
lebih memilih untuk tidak menampung sampah atau membuat TPSS (Tempat Pengumpulan Sampah Sementara) di wilayah tersebut. Pengelolaan sampah di sini mencontoh pengelolaan sampah di perkotaan, yaitu sistem "bongkar jual”.

Meskipun tidak 100\% mencontoh kegiatan pengelolaan sampah di wilayah perkotaan, di RT 45 ini menggabungkan teknik pengelolaan sampah yang ada di Sukunan Sleman. Di wilayah ini masingmasing rumah tangga memilah sampah di setiap tong pilah yang tersebar di wilayah RT 45 berjumlah 11 titik. Satu titik terdiri dari tiga tong pilah yaitu kertas, plastik, logam/kaca. Gambaran kegiatan pengelolaan sampah di wilayah ini dapat dicermati pada Gambar 2.

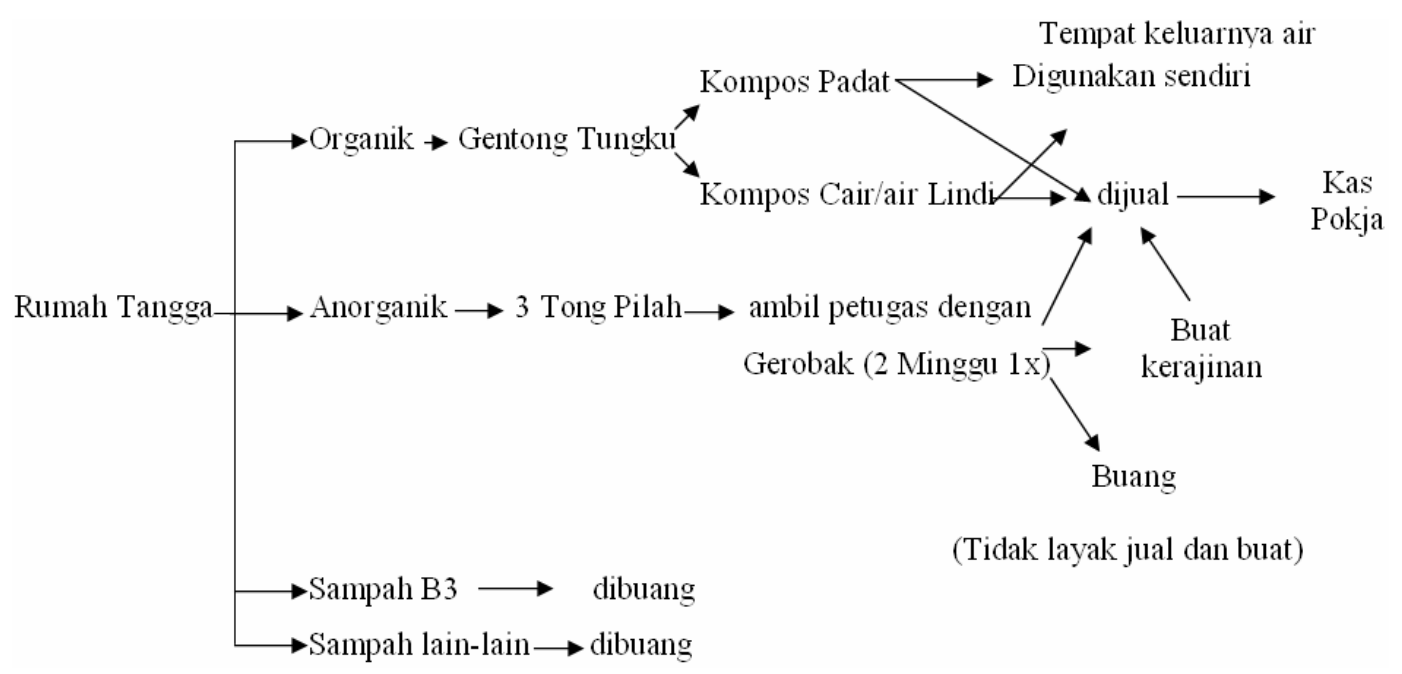

Gambar 2. Skema Pengelolaan Sampah di RT 45 Gambiran Lor

Kegiatan pengelolaan sampah di wilayah ini berawal pada saat diadakan program Kampung Hijau yaitu salah satu program Pemerintah Kota Yogyakarta yang peduli lingkungan. Untuk RT 45 Gambiran Lor sendiri bekerjasama dengan LSM Walhi. Pada awalnya kegiatan pengelolaan sampah di RT 45 Gambiran Lor merupakan gagasan dari LSM Walhi. LSM Walhi atau dikenal dengan sahabat lingkungan Walhi ini adalah LSM yang bekerjasama dengan Dinas Lingkungan Hidup Kota Yogyakarta. Kegiatan pengelolaan sampah di RT 45 ditangani oleh Pokja yang menangani lingkungan, terutama sampah. Untuk memancing semangat warga dalam kegiatan pengelolaan sampah, terutama untuk pembuatan pupuk, BAPEDALDA Propinsi Daerah Istimewa Yogyakarta memberi bantuan berupa cacing dan bibit tanaman.

\section{Pengelolaan Sampah di RW 01 Ngampilan, Ngampilan, Yogyakarta}

RW 01 Ngampilan memiliki jumlah penduduk 1.032 jiwa dengan luas wilayah 0,5 $\mathrm{Km}^{2}$. Wilayah ini memiliki kepadatan penduduk $2.064 \mathrm{jiwa} / \mathrm{km}^{2}$. Kepadatan penduduk yang tinggi merupakan salah satu kendala dalam kegiatan pengelolaan sampah. Untuk lahan kosong yang sama sekali tidak 
ada menyulitkan warga untuk menempatkan komposter-komposter yang ada. Setelah mengalami beberapa teknik yang diterapkan untuk kegiatan pengelolaan sampah, akhirnya wilayah Ngampilan RW 01 memiliki teknik sendiri dalam kegiatan pengelolaan sampah yang disesuaikan dengan kondisi dan situasi lokal. Adapun kegiatan pengelolaan sampah di wilayah ini dapat dilihat pada Gambar 3.

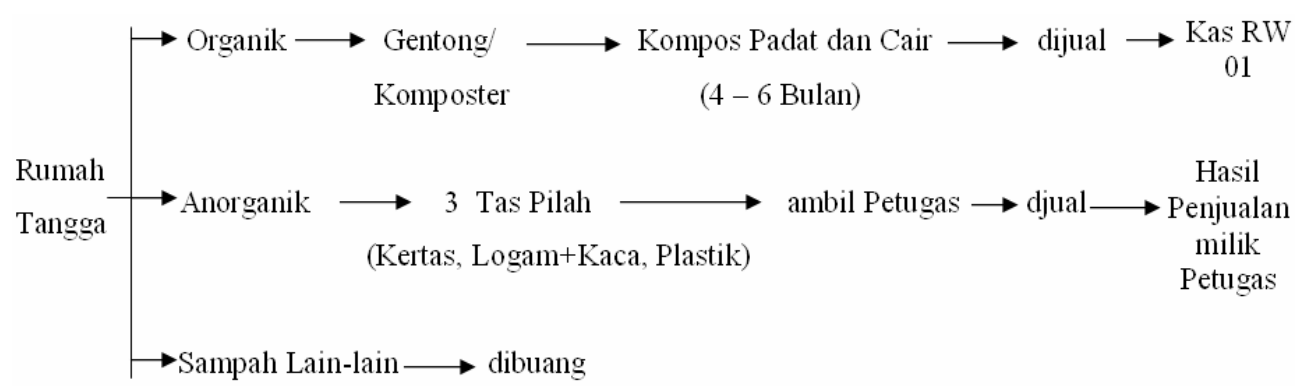

Gambar 3. Skema Pengelolaan Sampah di RW 01 Ngampilan

Tanggal 7 September 2005 adalah awal kegiatan pengelolaan sampah di RW 01 Ngampilan. Hal ini dilatarbelakangi oleh keluhan warga yang mulai merasakan lingkungan yang tidak bersih dan sehat. Sungai yang mengalir di wilayah RW 01 Ngampilan menjadi sasaran tempat pembuangan sampah. Warga meminta kepada pemerintah setempat yaitu lurah untuk mengadakan kegiatan pengelolaan sampah demi mengatasi masalah persampahan. Selanjutnya lurah menyerahkan kegiatan pengelolaan sampah kepada ibu-ibu PKK dibantu Dinas Lingkungan Hidup Kota Yogyakarta dan ESP (Environment Services Programme).

Memang jarak studi banding dan musyawarah kegiatan pengelolaan sampah sudah berlangsung sejak Maret sampai November tahun 2002, tetapi realisasinya baru di tahun 2005. Hal ini disebabkan oleh karena masih adanya pro dan kontra sebagian masyarakat tentang kegiatan pengelolaan sampah. Dengan presentase sebesar 50\% penduduk mulai aktif dalam kegiatan pengelolaan sampah. Masing-masing rumah tangga dianjurkan untuk memilah sampah anorganik pada 3 tas pilah yang selanjutnya akan diambil petugas setiap harinya dengan menggunakan gerobak sampah, sedangkan untuk sampah organik atau sampah dapur dimasukkan ke dalam komposter. Komposter ini jauh lebih mudah ditempatkan di mana saja, jadi tidak terlalu memakan tempat dan tidak mudah rusak seperti halnya genthong gerabah. Selain itu pupuk cair yang dihasilkan dalam waktu 7 x 24 jam atau 2 hari juga sangat baik untuk semua jenis tanaman.

\section{Pengelolaan Sampah di RW 06 Gamelan Lor, Panembahan, Kraton, Yogyakarta}

RW 06 Gamelan Panembahan merupakan wilayah yang mengelola sampah di Kecamatan Kraton yang bekerjasama dengan LSM Lestari, Dinas Lingkungan Hidup Kota Yogyakarta, dan DKKP. “Uwuh Sentana” atau singkatan dari Upaya Warga Untuk Hidup Sehat Nyaman Tertata Berguna 
adalah komunitas pengelolaan sampah mandiri di RW 06 Gamelan Panembahan. Di sini memang belum lama dalam kegiatan pengelolaan sampahnya, yaitu dimulai pada tanggal 27 Januari 2008. Namun demikian, 50\% penduduk bersemangat dan aktif dalam kegiatan pengelolaan sampah. Sampah yang awalnya merupakan masalah dan menimbulkan bau, di wilayah ini justeru diubah menjadi sesuatu yang sangat bermanfaat. Hal ini sesuai dengan prinsip warga di wilayah ini yang menganggap bahwa sampah bukan menjadi musibah, tetapi berkah. Di wilayah ini sampah organik pun dapat diubah menjadi pupuk yang sangat bermanfaat bagi tanaman. Sampah organik dibagi menjadi 2 (dua) kelompok yaitu sampah daun dan sampah dapur (sisa sayur, nasi, dsb).

Kedua jenis sampah organik ini dikelola dengan baik dengan cara yang berbeda. Untuk sampah dapur digunakan komposter cair atau ember yang diberi kran, namun untuk sampah pekarangan digunakan kompos tanam dan genthong tungku atau di wilayah ini disebut sebagai komposter kering atau gerabah.

Komposter kering atau gerabah ini juga dimanfaatkan untuk mempercantik taman yang hijau di masing-masing pekarangan rumah penduduk. Sebagian besar penduduk wilayah ini sangat gemar menanam, sehingga dengan adanya kegiatan pengelolaan sampah di wilayah ini banyak manfaatnya. Selain itu pupuk cair yang dihasilkan, dapat membuat pohon buah seperti mangga membuahkan hasil yang memuaskan. Kegiatan pengelolaan sampah yang dilakukan di wilayah ini dapat dicermati pada Gambar 4.

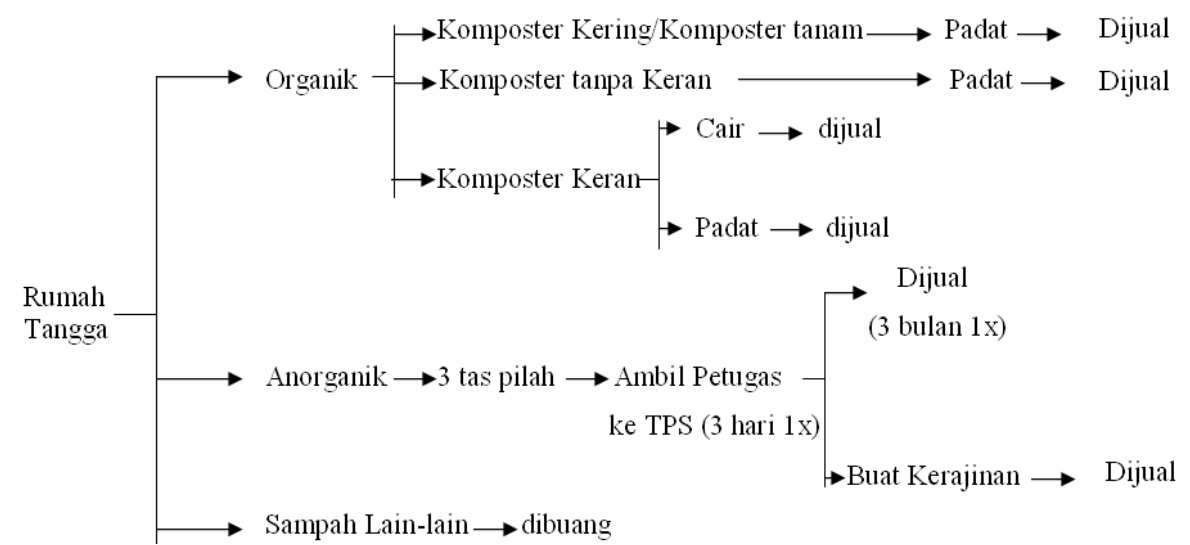

Gambar 4. Skema Pengelolaan Sampah di RW 06 Gamelan Panembahan

Walaupun demikian, tidak dipungkiri bahwa terdapat kendala dalam kegiatan pengelolaan sampah di wilayah ini. Pengelolaan sampah yang masih belum tepat dan pemulung yang sering mencuri sampah anorganik yang sudah dikumpulkan oleh warga, bahkan banyak peralatan yang digunakan untuk mengelola sampah diambil oleh pemulung merupakan masalah-masalah yang menjadi kendala dalam pengelolaan sampah di wilayah ini. 


\section{Pengelolaan Sampah di RW 05 Bugisan, Patangpuluhan, Wirobrajan, Yogyakarta}

Di wilayah ini memiliki jumlah penduduk 642 jiwa. Wilayah ini terletak di pinggir sungai Winongo. Dulu sebelum diadakan kegiatan pengelolaan sampah, warga Bugisan membuang sampah ke sungai sehingga sungai menjadi kotor. Setelah diadakan kegiatan pengelolaan sampah pada bulan Oktober 2007, masyarakat mulai mengurangi pembuangan sampah ke sungai.

Pada awalnya Kampung Bugisan ditunjuk oleh Kelurahan Ngampilan untuk menjadi wilayah yang mengelola sampah mandiri. Berawal dari penunjukkan tersebut untuk selanjutnya kegiatan pengelolaan sampah berlangsung di wilayah ini. Setelah beberapa bulan, masyarakat menyadari dan merasakan manfaat dari kegiatan pengelolaan sampah tersebut. Selain menjadikan lingkungan menjadi bersih dan sehat juga menghasilkan pendapatan tambahan dari kegiatan menjual sampah. Bugisan adalah wilayah perkotaan yang memiliki tingkat penjualan sampah yang di awal berjalannya yaitu rata-rata mencapai Rp 300.000 per penjualan.

Pengelolaan sampah di Bugisan dinamakan "Resik” merupakan singkatan dari Rapi Indah Sehat. Resik ini didampingi oleh LSM Lestari dan Dinas Lingkungan Hidup Kota Yogyakarta. Teknik yang digunakan dalam kegiatan pengelolaan sampah Resik adalah seperti yang digambarkan pada skema di bawah ini (Gambar 5).

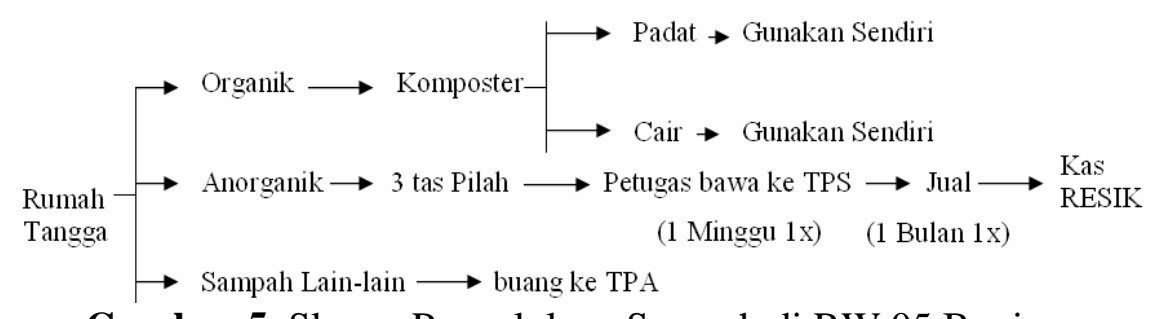

Gambar 5. Skema Pengelolaan Sampah di RW 05 Bugisan

Bugisan memiliki satu TPS yang berfungsi sebagai tempat pengumpulan sampah sementara dari rumah tangga-rumah tangga yang selanjutnya setiap 3 minggu sekali dijual ke pengepul. Namun pada saat penelitian ini kegiatan pengelolaan sampah vakum selama kurang lebih 2 bulan disebabkan masyarakat disibukkan dengan kesibukan masing-masing, apalagi pada waktu 17 Agustus, puasa ramadhan, dan lebaran. Masyarakat untuk memulai kembali masih malas-malasan atau dapat juga dikatakan mengalami penurunan semangat dalam kegiatan pengelolaan sampah. Di samping itu cuaca yang tidak mendukung seperti hujan pada waktu pengumpulan dan penjualan sampah juga menjadi kendala dalam pengelolaan sampah di wilayah ini. Sampai saat penelitian, penduduk yang aktif dalam mengelola sampah hanya 10\% saja. Walaupun penduduk sudah mengetahui keuntungan dari kegiatan pengelolaan sampah dan sekaligus dapat membantu pemerintah dalam mengatasi masalah tentang sampah namun semangat masyarakat belum dapat 
dipulihkan. Upaya Resik untuk mengajak penduduk kembali mengelola sampah yaitu berupa slogan-slogan agar mengelola sampah dengan baik dan mengurangi penggunaan tas plastik (kresek).

\section{Pengelolaan Sampah di RW 07 Jetisharjo, Cokrodiningratan, Jetis, Yogyakarta}

Jetisharjo RW 7 merupakan wilayah yang strategis, mudah dijangkau dan dekat dengan fasilitas pendidikan dan fasilitas umum. Namun, hal seperti ini mendorong masyarakatnya untuk konsumtif, sehingga produk sampah yang dihasilkan pun juga besar. Salah satu warga di Jetis yang mempunyai latar belakang pendidikan S2 lingkungan, merasakan bahwa lingkungan rumah tinggalnya sudah tidak nyaman, kotor, dan banyak polusi udara. Warga tersebut mengusulkan pada acara pertemuan warga untuk melakukan kegiatan pengelolaan sampah di lokasi RW 7 Jetisharjo. Akhirnya pada bulan Februari 2008 disepakati kegiatan pengelolaan sampah tersebut dengan di dampingi LSM Lestari dan Dinas Lingkungan Hidup Kota Yogyakarta. Kegiatan pengelolaan sampah di wilayah ini dapat dicermati pada Gambar 6.

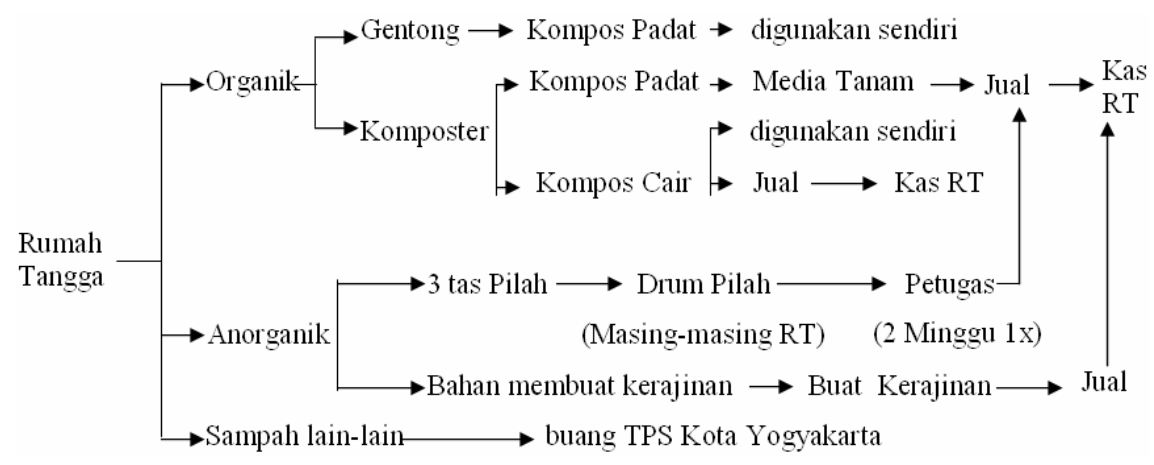

Gambar 6. Skema Pengelolaan Sampah di RW 07 Jetisharjo

Beberapa teknik untuk pengomposan sampah telah dilakukan yaitu pertama dengan menggunakan gentong gerabah. Ternyata setelah diterapkan di Jetisharjo memiliki banyak kelemahan. Hal ini disebabkan karena kondisi dan situasi Jetisharjo sudah padat penduduknya, dan rata-rata rumah yang ada tidak memiliki halaman, bahkan jalan hanya berupa gang kecil.

Kelemahan dengan menggunakan gentong gerabah yaitu sampah menjadi bau dan banyak lalat. Air hasil kompos atau lindi tidak bisa digunakan karena meresap ke bawah, karena di sana sudah tidak ada lagi tanah dan gang berupa konblok. Dengan demikian air lindi tersebut meresap ke konblok yang akhirnya menimbulkan bau yang tidak sedap. Di samping itu, setiap warga tidak bisa meletakkan gentong tersebut karena gentong memakan banyak tempat. Apabila diletakkan di jalan atau gang yang sempit, gentong mudah pecah karena terkena kendaraan yang lewat. Selain itu pengomposan dengan media gentong sangat lama. Proses menjadi kompos memakan waktu 5 sampai 6 bulan. Akhirnya digunakanlah teknik yang lain dalam pengomposan di wilayah ini yaitu dengan media komposter. 
Komposter ini berupa ember plastik atau bekas cat yang diberi kran air. Keuntungan dari menggunakan komposter ini yaitu tidak mudah pecah, penempatan yang ringkas. Di samping itu kran air yang yang digunakan dapat memudahkan air lindi untuk dituang atau ditampung. Air lindi ini selanjutnya digunakan sebagai pupuk tanaman, dijual, atau digunakan sebagai biang kompos yang fungsinya untuk mempercepat penguraian sampah menjadi kompos. Untuk mempercepat pembuatan sampah menjadi kompos selain dengan menggunakan air lindi, juga bisa menggunakan cacing, EM4, dan biostater yang dibuat sendiri dengan menggunakan bahan yang mudah dan murah. Bahan-bahan tersebut berupa pisang/kulit pisang, tempe busuk, nanas, dan bawang merah yang masing-masing dipotong kecil dan dilarutkan dalam satu gelas air gula.

\section{Pengelolaan Sampah di RW 09 Kricak Kidul, Kricak, Tegalrejo, Yogyakarta}

Pengelolaan sampah di Kricak dimulai pada bulan Juli 2008. Ide awal pengelolaan sampah oleh salah satu warga yang dilatar belakangi karena sudah merasa lingkungan tempat tinggalnya tidak sehat, timbul penyakit Demam Berdarah dan Malaria, bau yang tidak sedap, dan kotor. Hal ini disebabkan karena adanya sampah yang menggunung di samping rumahnya. Sampah yang menggunung tersebut adalah hasil buangan para penduduk, yaitu di pinggiran sungai. Penduduk membuang ke pinggiran sungai karena wilayah Kricak tidak terjangkau oleh layanan pemerintah seperti truk kuning pengangkut sampah.

Dengan adanya latar belakang seperti itu, warga mengusulkan untuk mengadakan kegiatan pengelolaan sampah mandiri. Dengan bekerjasama dengan LSM Lestari dan Dinas Lingkungan Hidup Kota Yogyakarta, Kricak melaksanakan kegiatan pengelolaan sampah mandiri. Masingmasing warga mulai memilah antara sampah organik dan sampah anorganik. Sampah organik dimasukkan ke dalam komposter atau ember berkran, dan sampah anorganik dipilah lagi menjadi 3 kelompok dengan tas pilah. Setelah dua minggu petugas mengambil sampah dari tiap rumah tangga untuk dibawa ke TPS. Di TPS akan dipilah kembali menjadi sampah layak jual, layak buat, dan layak buang. Sampah yang layak buang ini adalah sampah yang tidak laku dijual dan yang tidak bisa dibuat kerajinan. Untuk memperjelas kegiatan pengelolaan sampah yang diterapkan di sini dibuat bagan atau skema seperti Gambar 7.

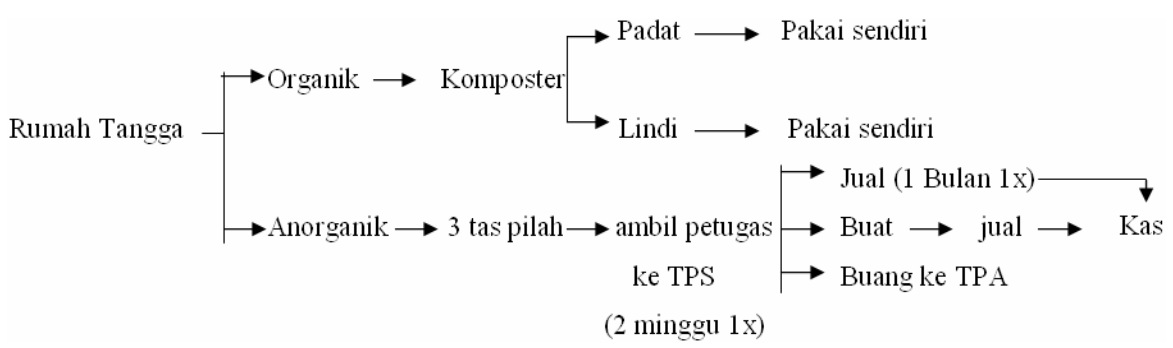

Gambar 7. Skema Pengelolaan Sampah di RW 09 Kricak Kidul 


\section{Pengelolaan Sampah di RW 22 Notoyudan, Pringgokusuman, Gedongtengen, Yogyakarta}

“Notokarep” atau singkatan dari Notoyudan Kampung Apik Resik Edhi Peni adalah suatu paguyuban pengelolaan sampah di RW 22 Kampung Notoyudan. Paguyuban ini menangani pengelolaan sampah berbasis masyarakat di Notoyudan khususnya RW 22. Kondisi lingkungan di sini hampir sama seperti di Ngampilan. Kondisi lingkungan yang tidak memungkinkan adanya lahan kosong sebagai sarana tempat pengumpulan sampah. Namun di wilayah ini terdapat TPS yang menempati lahan dengan status magersari (lahan milik Kraton Yogyakarta yang dipinjamkan kepada penduduk).

Awal mula kegiatan pengelolaan sampah yaitu tanggal 9 April 2008. Kegiatan pengelolaan sampah ini dilatar belakangi oleh perilaku sebagian masyarakat yang membuang sampah di sungai Winongo dan ke pekarangan kosong yang masih tersisa. Di bawah pekarangan yang biasa digunakan masyarakat untuk membuang sampah tersebut, terdapat rumah tinggal penduduk. Apabila sampahsampah tersebut terus melimpah, besar kemungkinan akan roboh menimpa rumah tinggal penduduk.

Akhirnya Dinas Lingkungan Hidup Kota Yogyakarta menunjuk Notoyudan untuk mengelola sampah mandiri. Dinas Lingkungan Hidup Kota Yogyakarta juga menunjuk LSM Lestari untuk mendampingi Notoyudan dalam kegiatan pengelolaan sampah. Meskipun demikian, masih sangat sulit sekali untuk merubah perilaku masyarakat, sehingga hanya sebesar 5\% masyarakat yang ikut dalam kegiatan pengelolaan sampah.

\section{Pengelolaan Sampah di Gedongkiwo, Mantrijeron, Yogyakarta}

Tanggal 15 Juni 2006 kegiatan pengelolaan sampah di Gedongkiwo diresmikan oleh Walikota Yogyakarta dengan nama TPSG atau Tim Pengelola Sampah komunal Gedongkiwo. Masyarakat Gedongkiwo pada awalnya mengelola sampah secara mandiri. Namun demikian karena mengalami kerugian atau defisit terus menerus maka untuk sekarang ini sudah bergeser menjadi tempat pembuatan kompos padat dengan bantuan alat atau mesin pencacah dan penghancur sampah. Dengan demikian hanya sampah-sampah dengan ukuran tertentu yang dapat masuk ke dalam mesin pencacah dan penghancur sampah yang bisa dikelola. Untuk sampah-sampah yang lain yang tidak dapat masuk ke dalam mesin pencacah dan penghancur sampah tidak dikelola yaitu sampah dapur seperti nasi, sisa sayuran, sisa lauk, dsb.

Untuk sampah anorganik juga tidak dikelola. Petugas pengambil sampah yang biasanya mengambil sampah-sampah itu dari tiap rumah tangga yang selanjutnya dijual sendiri oleh petugas tersebut. Namun, hanya sampah-sampah anorganik yang laku dijual tinggi yang diambil oleh petugas. 
Sampah-sampah anorganik lainnya yang tidak laku dijual oleh petugas dibuang ke Tempat Pembuangan Sampah Sementara Kota Yogyakarta. Berikut adalah skema pengelolaan sampah di Gedongkiwo (Gambar 8).

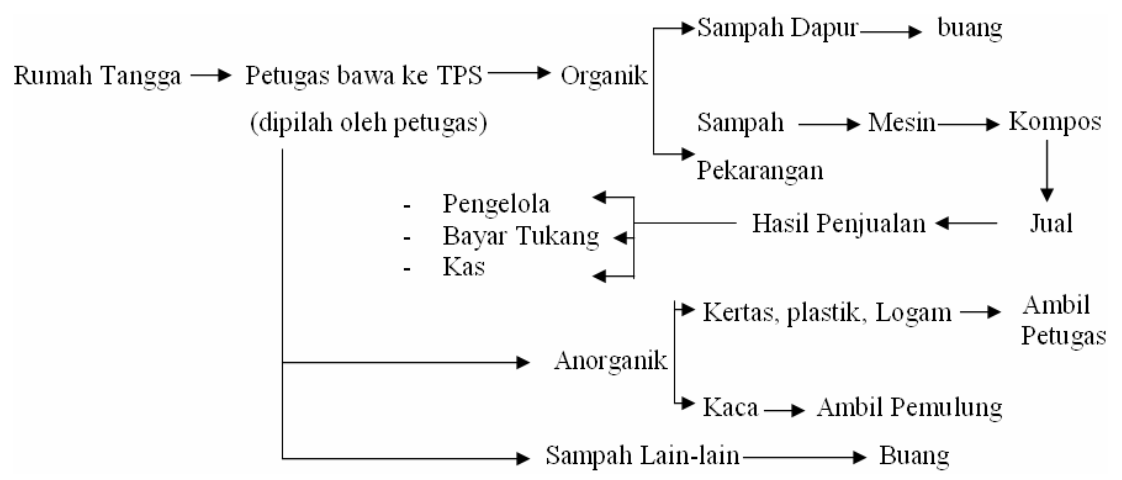

Gambar 8. Skema Pengelolaan Sampah Di Gedongkiwo

\section{Kesimpulan dan Saran}

Dari analisis dan pembahasan mengenai upaya peningkatan pengembangan pengelolaan sampah secara mandiri yang dilakukan oleh masyarakat perkotaan di Kota Yogyakarta, maka dapat disimpulkan kegiatan pengelolaan sampah yang sudah diterapkan di beberapa lokasi penelitian sudah cukup baik yaitu di Gondolayu Lor, Gambiran Lor, Gamelan, Bugisan, Jetisharjo, dan Kricak. Penelitian ini juga menyimpulkan bahwa masyarakat perkotaan di Kota Yogyakarta mengembangkan tiga model pengelolaan sampah dan untuk model yang paling baik yaitu memilah antara sampah organik, anorganik, B3 (Bahan Beracun Berbahaya), dan sampah lain-lain.

Agar kegiatan pengelolaan sampah dapat terlaksana secara optimal diperlukan adanya partisipasi dari berbagi pihak. Baik pemerintah maupun tokoh masyarakat perlu melakukan sosialisasi maupun fasilitasi program-program pengelolaan sampah. ekonomi yaitu sosialisasi melalui bidang masingmasing dalam hal pengelolaan sampah. Di sisi lain masyarakat dituntut kesadaran, partisispasi, dan keaktifan dalam hal pengelolaan sampah.

\section{Daftar Pustaka}

Basriyanta. (2007). Memanen Sampah. Yogyakarta: Kanisius.

Outerbridge, Thomas. (1991). Limbah Padat di Indonesia: Masalah atau Sumber Daya. Jakarta: Yayasan Obor Indonesia.

Rineksa, Setiawan. (Oktober, 2007). Mengurangi Sampah tanpa rupiah. Buletin Lingkungan Hidup Kalpataru, hal. 2-4.

Sucipto, R. H. (Maret, 1998). Sampah Membayangi Wajah Jakarta. Pro LH, hal 4. 